\title{
Explaining a Model for the Effects of High Commitment Human Resource Management
}

Valiollah Mirzaei Alamooti ${ }^{1}$ Ph.D. in Human Resource Management, Department of Public Administration, Qazvin Branch, Islamic Azad University, Qazvin, Iran (Corresponding Author).

Mohammad Ataei ${ }^{2}$ Assistant Professor, Department of Public Administration, Qazvin Branch, Islamic Azad University, Qazvin, Iran.

Zohreh Moghaddas ${ }^{3}$ Assistant Professor, Department of Mathematics, Qazvin Branch, Islamic Azad University, Qazvin, Iran.

Received: 12/05/2019 | Accepted: 13/04/2020

\begin{abstract}
Purpose: Effective and efficient human resource management is critical to the success of any organization. Meanwhile, improving employee performance is one of the main concerns of organizations in the public sector.

Methodology: The aim of this study is to design a high commitment human resource management (HC-HRM) model among the employees of the 14 regions of Education Department in Qazvin Province. The statistical sample consisted of 260 employees who were selected according to the Morgan table. The present study was of a survey type. Data analysis was performed by applying structural equation modeling and Smart PLS2 software.

Findings: Research results show that perceived high commitment human resource management directly and positively affects individual performance. In addition, research findings indicate that the variables of work engagement, professional commitment, and perceived organizational support play a role in the relationship between high commitment human resource management and individual performance as mediators.

Originality/ Value: No doubt, the findings of this study enhance the knowledge of high commitment human resource management; besides, by modeling perceived high commitment human resource management at individual level, it helps create a new knowledge domain in the related literature.
\end{abstract}

Keywords: High Commitment Human Resource Management (HC-HRM), Individual Performance, Ability-Enhancing Practices, MotivationEnhancing Practices, Opportunity-Enhancing Practices.

1.mirzaei.vali@qiau.ac.ir

2. ataei@qiau.ac.ir

3.zmoghaddas@qiau.ac.ir 


\section{عنوان مقاله: مدل تبيين آثار مديريت منابع انسانى متعهدانه}

\section{ولى اله ميرزايى الموتى'، محمد عطايى'، زهره مقدسج}

مقاله يثوهشى

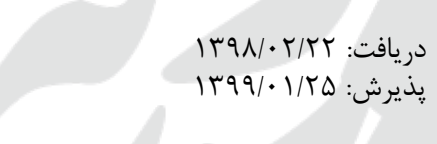

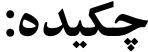

هدف: مديريت موثر و كارامد منابع انسانى براى موفقيت هر سازمان حياتى است. ارتقاى

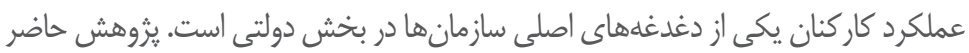

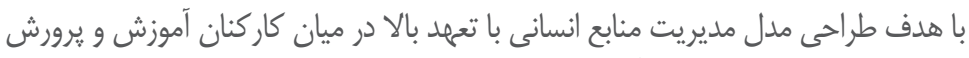

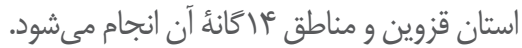

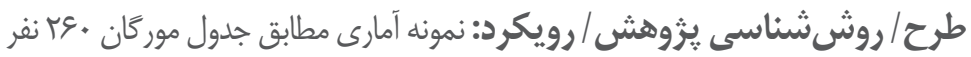

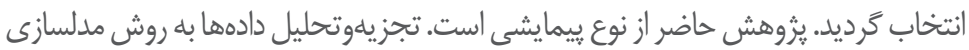

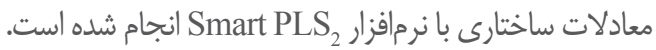
$\sum^{2}$

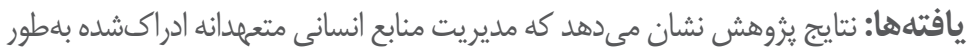

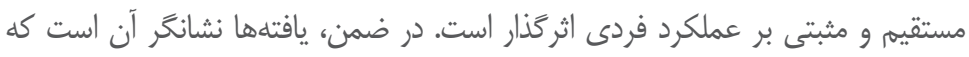

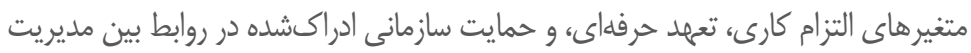

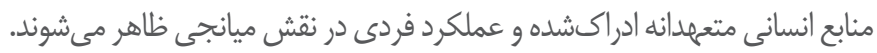

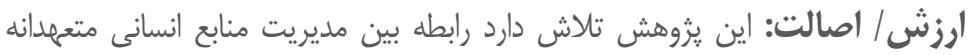

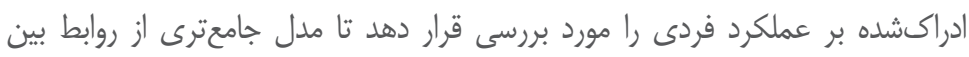

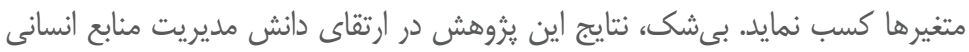

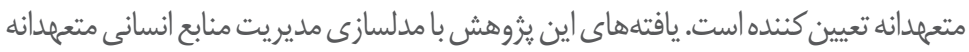

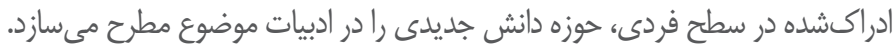
كليدوازهها: مديريت منابع انسانى متعهدانه، عملكرد فردى، اقدامهاى

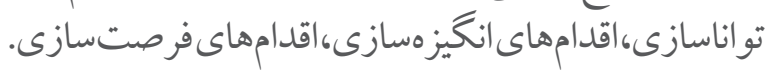

ا. دكترى مديريت منابع انسانى، گروه مديريت دولتى، واحد قزوين، دانشكاه آزاد اسلامى، قزوين، ايران mirzaei.vali@qiau.ac.ir

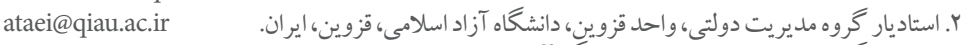

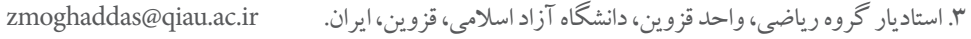




\section{مقدمه}

از دو دهه كذشته، يثوهشگران در مديريت منابع انسانى راهبردى بررسى مى كنند كه جرا

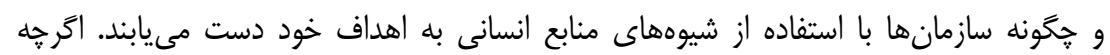
يثوهشهاى مديريت منابع انسانى سنتى بر تاثير شيوههاى فردى منابع انسانى متمركز است، ديدگًاه راهبردى در يزوهش مديريت منابع انسانى بر بستههاى شيوههاى منابع انسانى، اغلب به له

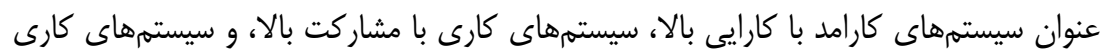
با تعهد بالا تاكيد دارد. يك جنبش رو به رشد از يزوهشهان هاى حوزه مديريت منابع انسانى راهبردى

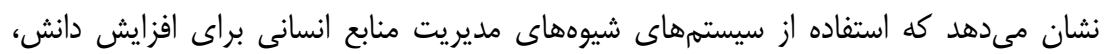
مهارتها و توانايىها، و انخيزه و فرصت كاركنان براى مشاركت با ييامدهاى مثبتى مانند تعهد بيشتر، جابهجايى كمتر، بهرهورى با كيفيت بالاتر، عملكرد بهتر خدمات، بهبود عملكرد ايمنى، و عملكرد مالى بهتر همراه است (Jiang et al., 2012). در دها كذشته، شواهد نشان مىدهد كه رابطه مثبتى بين مديريت منابع انسانى و عملكرد سازمانى وجود دارد. اين شواهد از الاعتقاد عقلانى" بلشدت حمايت مى كند، زيرا بهبود نحوه مديريت افراد بلهور اجتنابنايذيرى به به بهبود

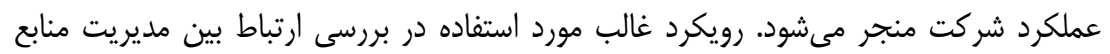
انسانى و عملكرد، مديريت منابع انسانى را به عنوان يك مجموعه ايدهآل از شيوهها مورد توجه

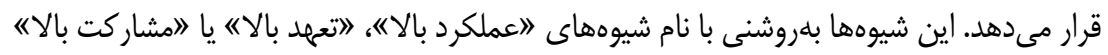
در نظركرفته مىشوند، زيرا به نظر مىرسد ذخاير استفادهنده از اهنابع انسانى" با افزايش تعهلد و مشاركت كاركنان آزاد مىشود (Gould-Williams, 2004). عملكرد اصلى مديريت سازمانى مدرن، مانند افزايش توانايى و انخيزه كار كنان، بيشينه كردن رضايت شغلى و عملكرد سازمانى است (Kang \& Kang, 2016). افراد در سازمان ها بلهطور فزايندهاى به عنوان يك منبع كليدى براى ايجاد ارزش شناخته مىشوند. بلطور خاص، جذب و حفظ كاركنان با دانش بالا، كه داراى سطوح عملكرد بسيار بالا هستند، مىتواند بلطور قابلتوجهى بر اثربخشى سازمان اثر بحذاردئ يزوهشگَران معتقدند حفظ و نكَهدارى عملكرد برتر بر كارايى سازمانى اثر مى گذارد، زيرا انتقال آنها نهتنها هزينههاى جايخزينى را افزايش مى دهد، بلكه موجب كاهش روحيه سازمانى مىشود. با توجه به رقابت جهانى مبتنى بر دانش، به نظر مىرسد كه اهميت حفظ عملكرد برتر به دليل تهديد بالقوه انتقال 
دانش ارزشمند توسط اعضاى برتر به سازمانهاى رقيب تقويت مىشود (Kwon et al., 2010). منافع شديد در زمينه مديريت منابع انسانى در مورد اين كه جَّونه مديريت منابع انسانى مىتواند ارزش سازمان را افزايش دهد، به تمركز بيشتر بر سيستمهاى كارى با عملكرد بالا منجر مى مئسود. در عين حال، مفسران بلطور فزايندهاى در مورد نياز به تجديدنظر در يزوهشهاى موجود براى رفع برخى از ضعفهاى روششناختى در اين حوزه مىيردازند. يك مسئله اين است كه بسيارى

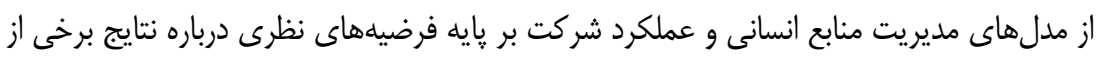
شيوههاى مديريت منابع انسانى بلجاى مشاهدههاى تجربى مبتنى هستند. كَست (199V)، همجرنين از ديدگًاه كاركنان در اين بحث همراه با متغيرهاى رايج سطح سازمانى استفاده مى كند. مديريت منابع انسانى اثربخش براى موفقيت هر سازمانى حياتى است. كيفيت منابع انسانى سازمان، احساس افراد

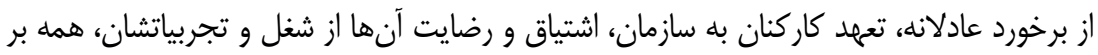

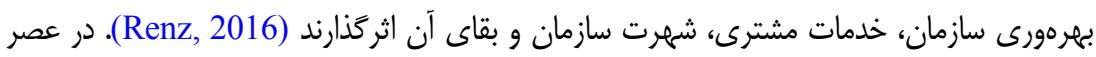
جهانى شدن و ييشرفت سريع فناورى، سرمايه انسانى به عنوان مهمترين سرمايه سازمان ها قلمداد

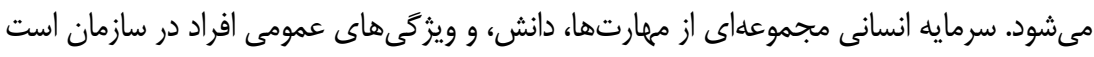
كه مىتواند نشاندهنده ظرفيت انجام كار امروز و ظرفيت بالقوه كار فردا باشد (Hitt et al., 2006). عملكرد فردى يك معيار سنجش مرتبط و اغلب مورد استفاده در محيط حرفهاى است. در

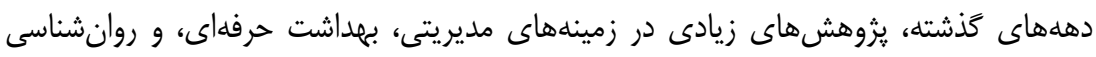

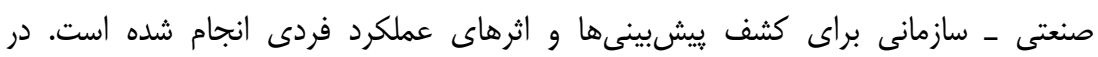
ادامه، توجه بيشترى به تعريف ساختار عملكرد فردى و درى ساختار اصلى آن صورت گرفت

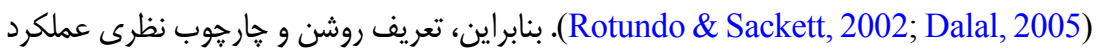
كار فردى، يك يِيش شرط براى اندازهگيرى معتبر از ساختار است. در اين يزوهش، تمركز ما بر درى كاركنان مديريت منابع انسانى متعهدانه است كه بهطور خاص به منظور افزايش اثربخشى سازمانى با اثر نخرشهاى فردى (يعنى تعهد) مىيردازد (Boon \& Kalshoven, 2014). اين يزوهش تلاش دارد رابطه بين مديريت منابع انسانى متعهدانه ادراكشده بر عملكرد فردى را مورد بررسى قرار دهد تا مدل جامعترى از روابط بين متغيرها كسب نمايد. بىشك، نتايج اين يزوهش در ارتقاى دانش مديريت منابع انسانى متعهدانه تعيين كننده است. يافتههاى اين يزوهش با مدلسازى مديريت منابع انسانى متعهدانه ادراكشده در مر مرئر سطح فردى، حوزه دانش جديدى را در ادبيات موضوع مطرح مىسازد. 


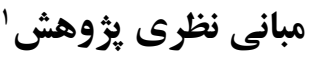

\section{مديريت منابع انسانى متعهدانه}

برخلاف ادبيات گَترده در خصوص مديريت منابع انسانى متعهدانهَ در سازمانهاى بخش خصوصى، يزوهشهاى صورتكرفته در سازمانهاى دولتى بسيار محدود است (Farnham \& Giles, 1996; Boyne et al., 1999; Hays \& Kearney, 2001) سازمانهاى دولتى بر استانداردسازى اقدامهاى منابع انسانى تاكيد مىشود، اما تاكيد بر آموزش

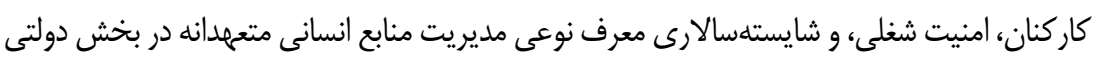
است. بنابراين، انتظار مىرود كه هنين سيستمهايى به تربيت كاركنان متعهد و باانكيزه منجر شود، اما

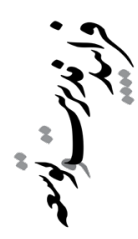
اين جيزى نيست كه در عمل مشاهده مى شود (Osborne \& Pasterik, 1997; Boyne, 2002). شايد يك دليل، اين كفته باشد كه رفتار حمايتى بيش از حد بلنوعى به تنبلى كاركنان منجر شده است. دليل ديكر اين مغايرت را بايد در اقدامهاى عملى منابع انسانى جستجو كرد كه با وجود تاكيد

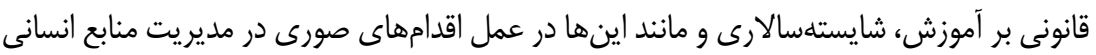

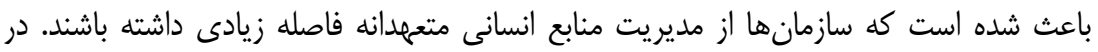
ضمن، وجود خطمشىهاى استانداردسازى در زمينه مديريت منابع انسانى به اين معنا نيست كه در عمل تمامى سازمانهاى دولتى از سيستم واحدى در مديريت منابع انسانى استفاده مى كنند. براى مثال، سيستمهاى مديريت منابع انسانى در سازمانهاى دولتى با مقررات استخدامى خاص بيشتر شبهازار هستند (Boyne et al., 1999). مديريت منابع انسانى متعهدانه يكى از سيستمهاى

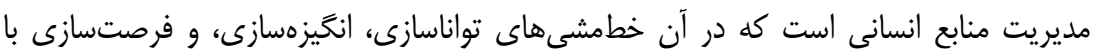

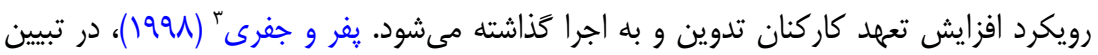

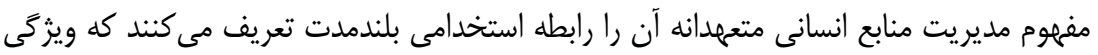

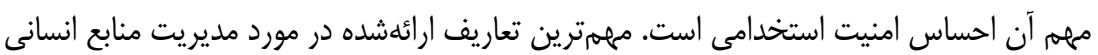
با تعهد بالا به شرح جدول (1) است.

2. High Commintment Human Resource Management (HC-HRM)

3. Pfeffer \& Jeffrey

ا. متن اين بخش توسط ويراستار كوتاه شده است. 
جدول 1: تعاريف مديريت منابع انسانى متعهدانه

\begin{tabular}{|c|c|c|}
\hline تعاريف & منبع & رديف \\
\hline 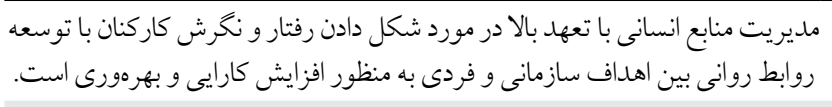 & 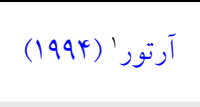 & 1 \\
\hline 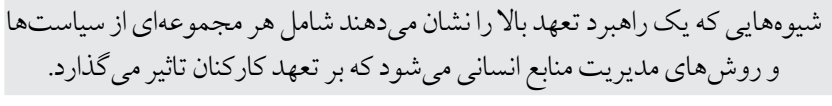 & 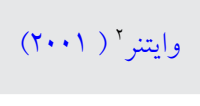 & r \\
\hline 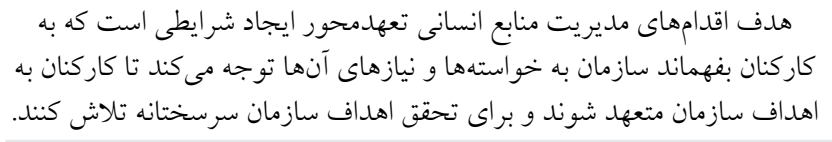 & 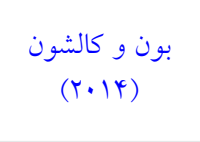 & $r$ \\
\hline 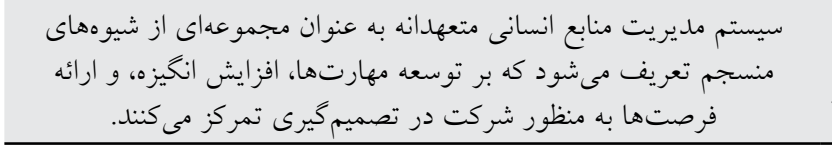 & 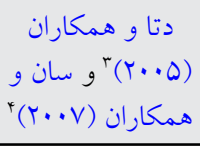 & r \\
\hline
\end{tabular}

\section{سنجش مديريت منابع انسانى متعهدانه}

سيستم مديريت منابع انسانى متعهدانه در سطح فردى را مىتوان بر مبناى ادراك كاركنان

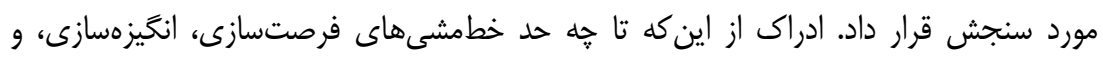

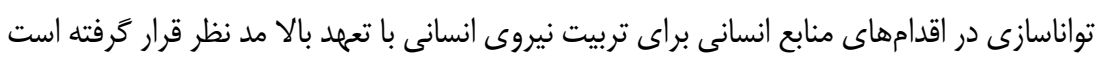

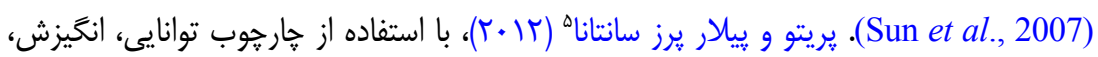
و فرصت (AMO)؛ مديريت منابع انسانى متعهدانه ادراكشده را بر مبناى ابعاد سهكانه به شرح

$$
\text { جدول (r) مورد سنجش قرار مىدهند. }
$$

1. Arthur

2. Whitener

3. Datta et al.

4. Sun et al.

5. Prieto \& Pilar Pérez Santana

6. Ability, Motivation, and Opportunity-Enhancing (AMO) 
جدول r: ابعاد و مولفههاى سنجش مديريت منابع انسانى متعهدانه (Prieto \& Pilar Pérez Santana, 2012)

\begin{tabular}{|c|c|c|}
\hline مولفه ها & ابعاد & سازه \\
\hline
\end{tabular}

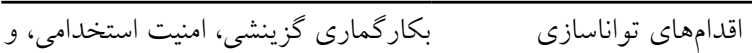

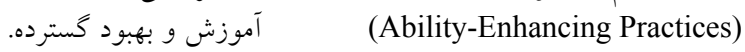

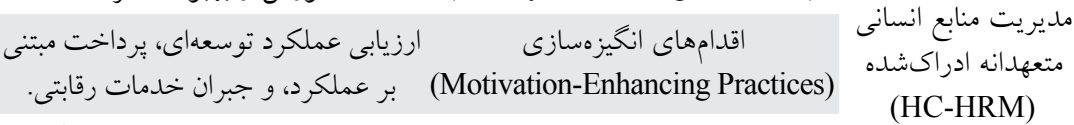

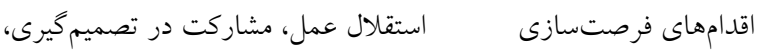

(Opportunity-Enhancing Practices)

\section{مدل مفهومى بزووهش}

با توجه به مبانى نظرى مديريت منابع انسانى متعهدانه، و با در نظركَرفتن ييشينه يزوهش،

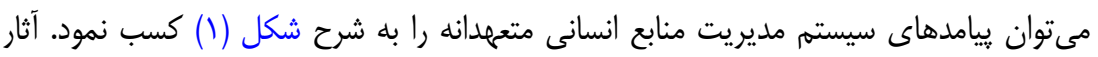

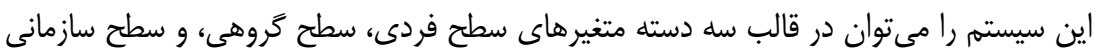
دستابندى كرد. به علاوه، برخى از متغيرها در نقش ميانجى ظاهر مى الشوند.

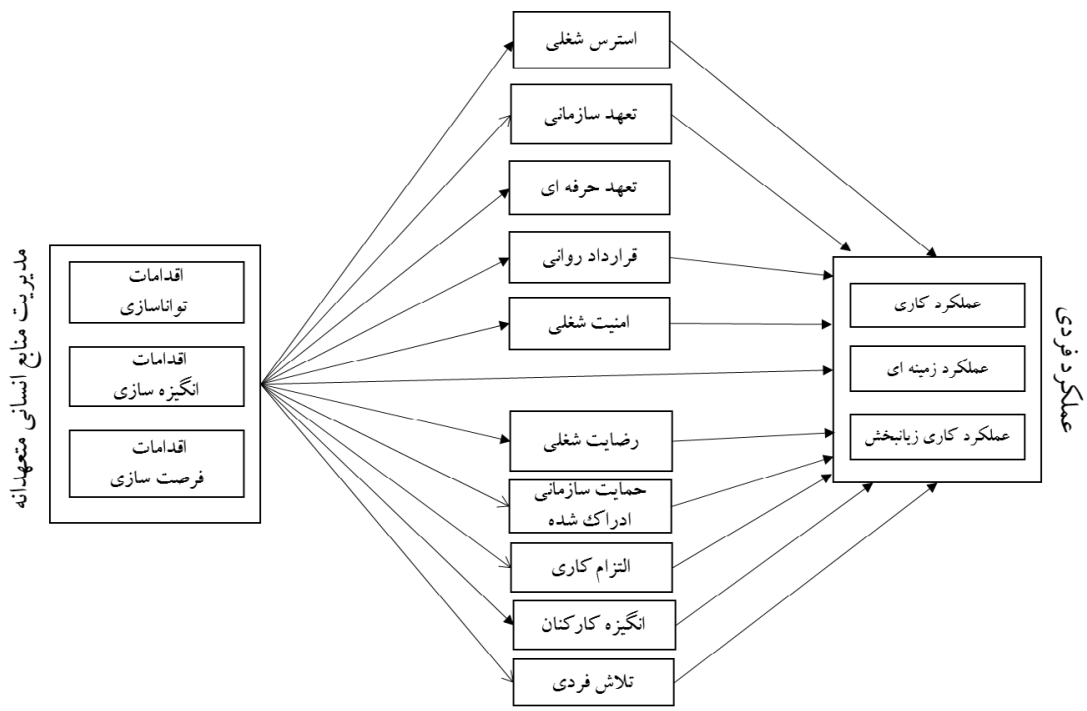

شكل 1: مدل مفهومى آثار مديريت منابع انسانى متعهدانه 
همان طور كه در شكل ( (1) ديده مى شود، مطالعات كَذشته بر آثار مديريت منابع انسانى متعهدانه

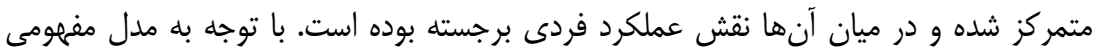
يزوهش، فرضيههاى يزوهش ارائه مىشود:

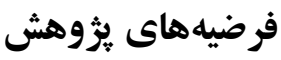

H: مديريت منابع انسانى متعهدانه بر عملكرد فردى اثر مثبت و معنادار دارد.

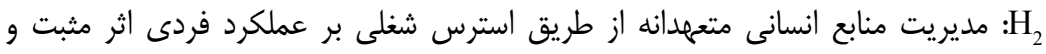

مدير

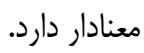

H معنادار دارد. - م مدري

H

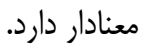

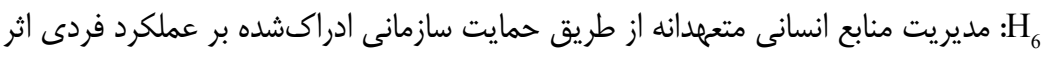

$$
\text { مثبت و معنادار دارد. }
$$

مارد

مار

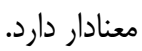
دار

H معنادار دارد. - م مدير

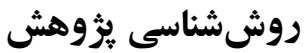

يزوهش حاضر از نظر هدف كاربردى و از نظر نحوه گردآورى اطلاعات توصيفى -همبستخى است. براى بررسى مدل و آزمون فرضيهها از مدلسازى معادلات ساختارى مبتنى بر PLS استفاده شده است، 
به دليل آن كه واحد تحليل در اين ثروهش فرد است. همجِنين سيستم مديريت منابع انسانى متعهدانه

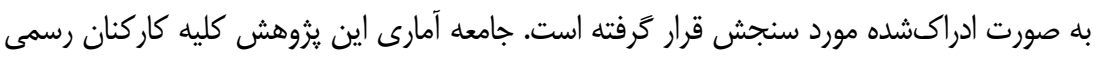

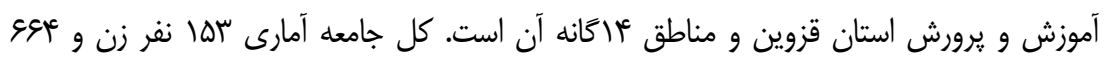

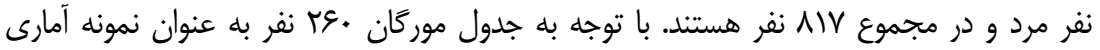

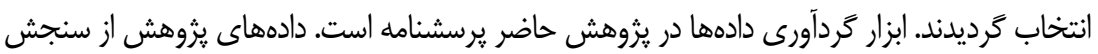
مديريت منابع انسانى متعهدانه ادراكشده (Prieto \& Pilar Pérez Santana, 2012)، عملكرد فردى ترى بردي (Koopmans et al., 2014)، استرس شغلى (Keller, 1994; Kang \& Kang, 2016)، تعهد سازمانى (Meyer \& Allen, 1997)، تعهد حرفهاى (Jauch et al., 1978)، قرارداد روانى (K) (Rousseau, 2000)، امنيت شغلى (Price, 1997)، رضايت شغلى (Price, 1997)، انخَيزه كاركنان(Cruz et al., 2009)، حمايت سازمانى ادراكشده (Eisenberger et al., 1986)، التزام كارى (Schaufeli et al., 2001)، و تلاش فردى (Brown \& Leigh, 1996) گَردآوى شده

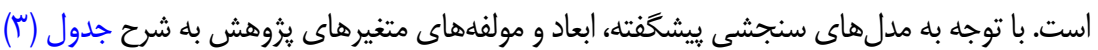

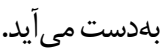

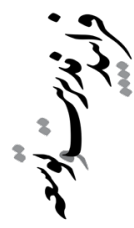


جدول r: ابعاد و مولفههاى سنجش متغيرهاى سطح فردى

\begin{tabular}{|c|c|c|}
\hline ابعاد و مولفه هاى سنجش & منبع & 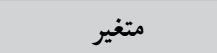 \\
\hline 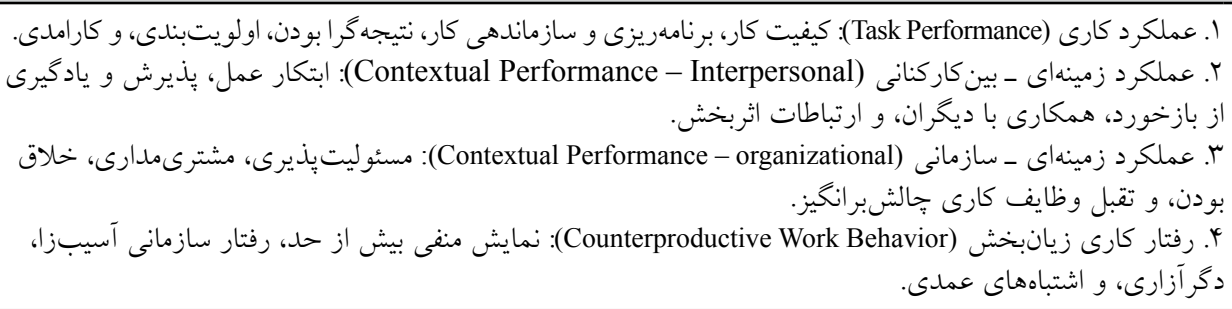 & $\begin{array}{l}\text { (Koopmans et al., } \\
\text { 2014) }\end{array}$ & $\begin{array}{l}\text { عملكرد فردى } \\
\text { Individual) } \\
\text { (Performance }\end{array}$ \\
\hline 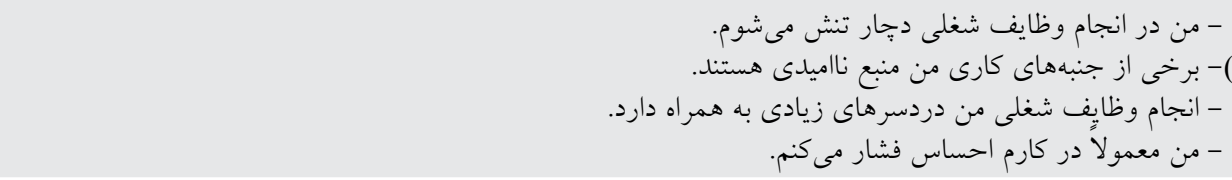 & $\begin{array}{l}\text { Keller, 1984; Kang } \\
\text { \& Kang, 2016) }\end{array}$ & استرس شغلى \\
\hline 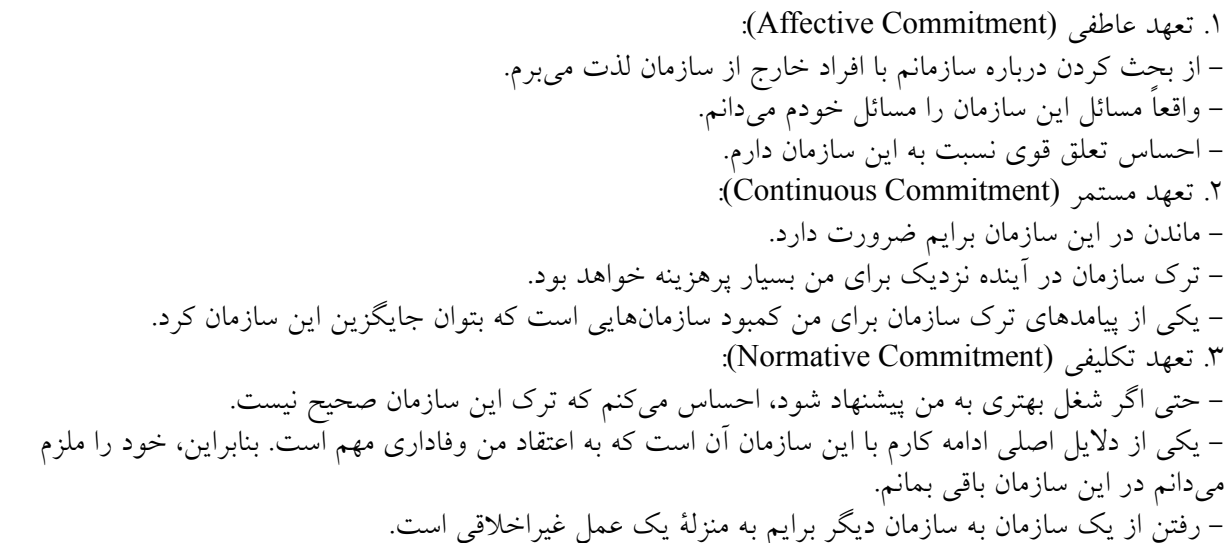 & $\begin{array}{c}\text { (Meyer \& Allen, } \\
\text { 1997) }\end{array}$ & $\begin{array}{c}\text { تعهد سازمانى } \\
\text { Organizational) } \\
\text { (Commitment }\end{array}$ \\
\hline
\end{tabular}


ادامه جدول "ז: ابعاد و مولفه هاى سنجش متغيرهاى سطح فردى

\begin{tabular}{|c|c|c|}
\hline ابعاد و مولفه هاى سنجش & منبع & متغير \\
\hline 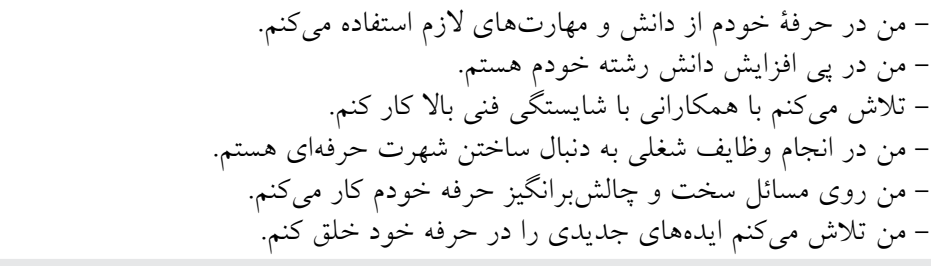 & (Jauch et al., 1978) & $\begin{array}{l}\text { تعهد حرفهاى } \\
\text { Professional) } \\
\text { (Commitment }\end{array}$ \\
\hline 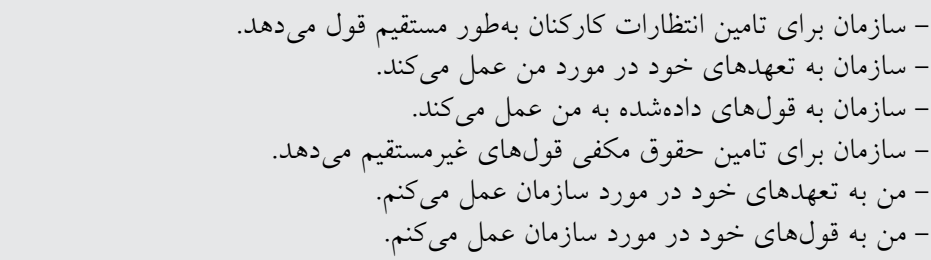 & $\begin{array}{l}\text { (Rousseau, 2000; } \\
\text { Rousseau \& Schalk, } \\
\text { 2000) }\end{array}$ & $\begin{array}{l}\text { قرارداد روانى } \\
\text { Psychological) } \\
\text { (Contract }\end{array}$ \\
\hline 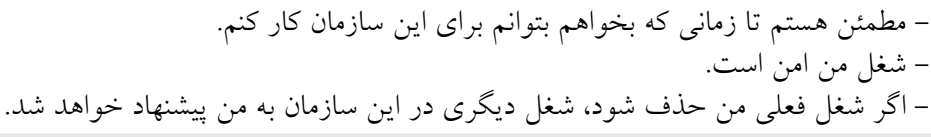 & (Price, 1997) & 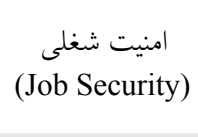 \\
\hline 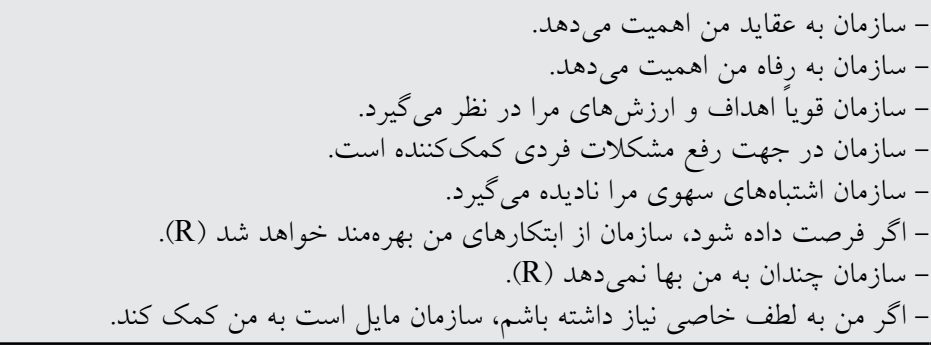 & $\begin{array}{l}\text { (Eisenberger et al., } \\
1986)\end{array}$ & $\begin{array}{l}\text { حمايت سازمانى ادراكشهه } \\
\text { (POS) }\end{array}$ \\
\hline
\end{tabular}

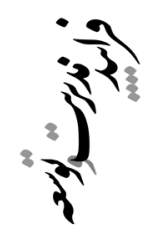

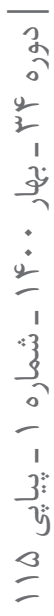


ادامه جدول بّ: ابعاد و مولفههاى سنجش متغيرهاى سطح فردى

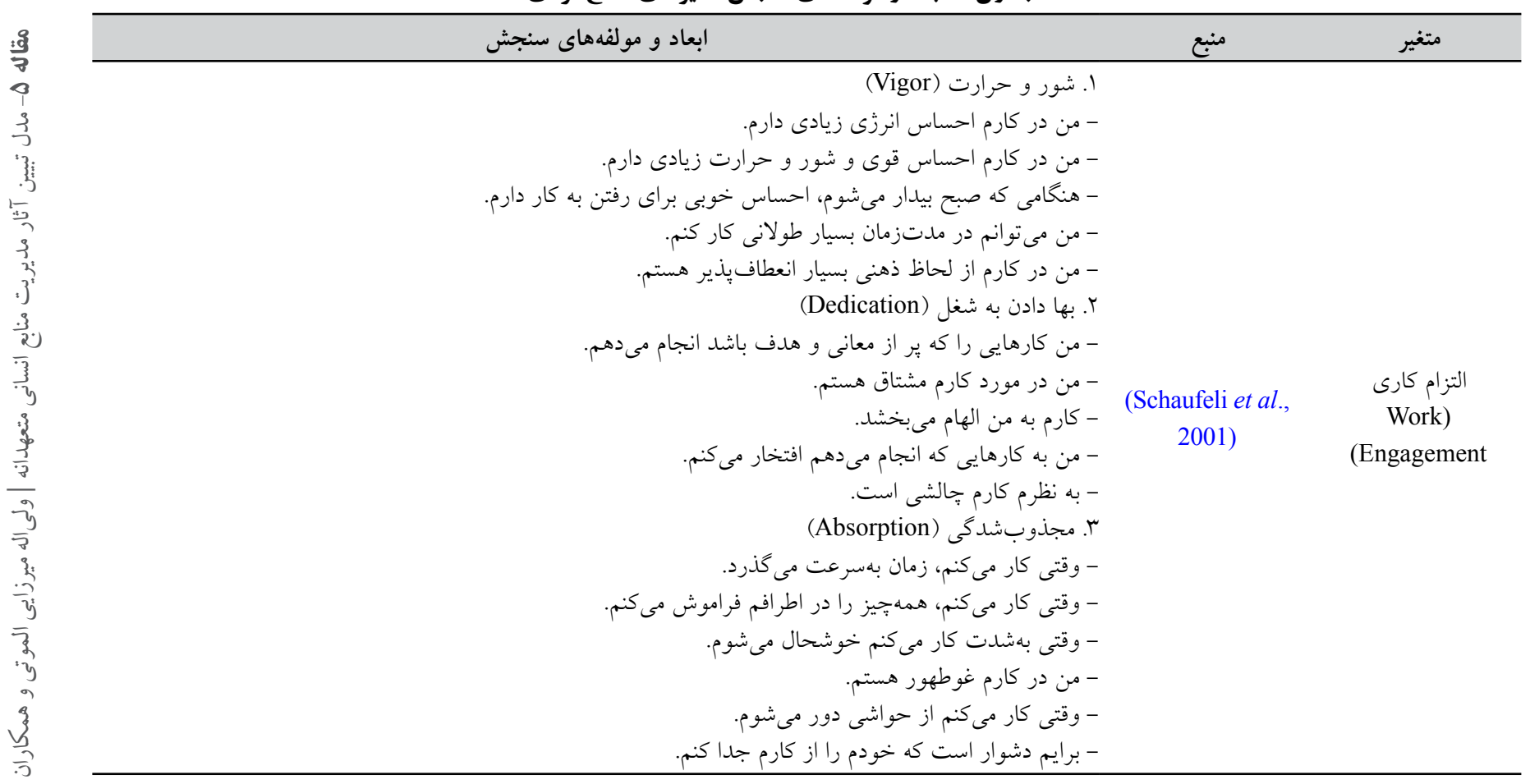


ادامه جدول r: ابعاد و مولفهاى سنجش متغيرهاى سطح فردى

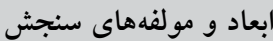

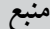

متغير

انخيزه بيرونى (Extrinsic Motivation)

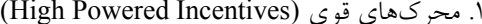

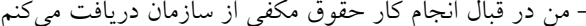

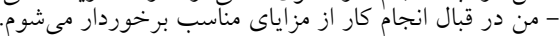

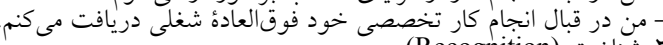

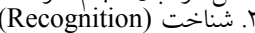

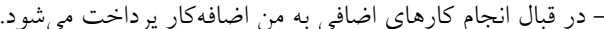

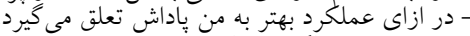

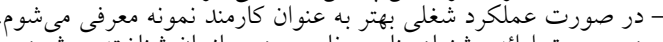

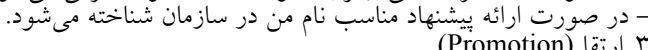

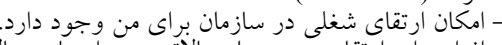

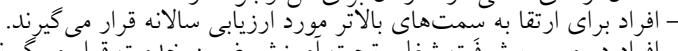

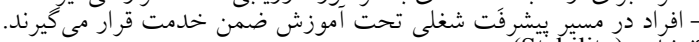

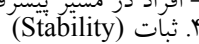

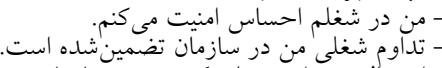

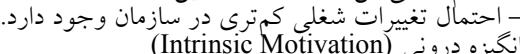

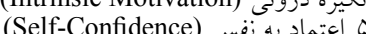

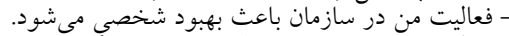

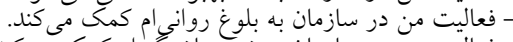
- فعاليت من در سازمان به خودساختكى بلى ام كمك مى كند.

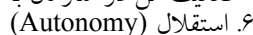

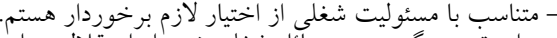

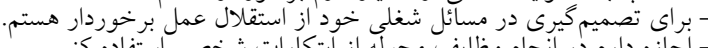

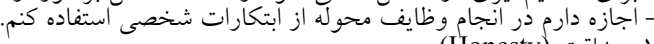

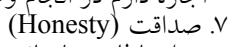

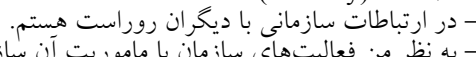

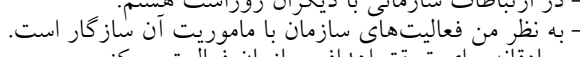

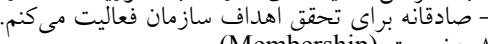

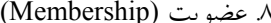

- تعلق خاطر زيادى به سازمان خون بود دارم. Employee)

(Motivation

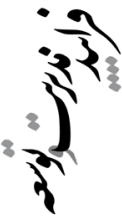


ادامه جدول ז: ابعاد و مولفههاى سنجش متغيرهاى سطح فردى

\begin{tabular}{|c|c|c|c|}
\hline$\stackrel{8}{3}$ & ل & منبع & 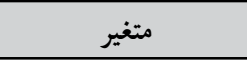 \\
\hline 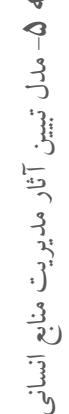 & 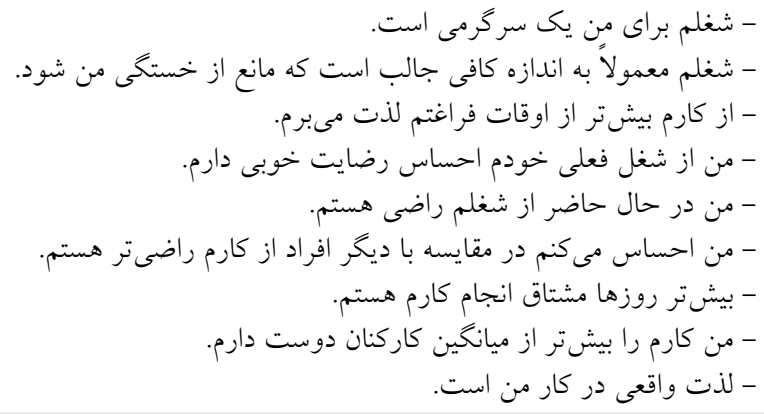 & (Price, 1997) & رضايت شغلى ) \\
\hline$\frac{3}{3}$ & 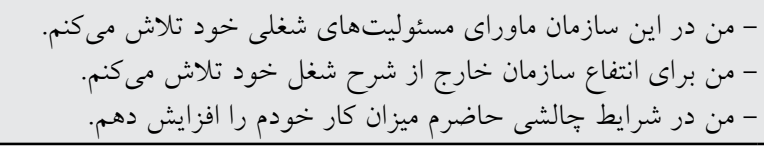 & $\begin{array}{l}\text { (Brown \& Leigh, } \\
\text { 1996) }\end{array}$ & $\begin{array}{c}\text { تلاش فردى } \\
\text { (Individual Effort) }\end{array}$ \\
\hline
\end{tabular}


لازم به توضيح است كه آلفاى كرونباخ تمامى برسشنامه بالاتر از / • بهدست آمد. همحِنين،

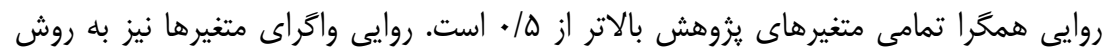
ماتريس فورنل-لاركر محاسبه شد كه در حد مناسبى بود.

\section{تجزيلوتحليل دادههاى ثئوهش}

با توجه به مدل مفهومى اين يزوهش كه به صورت ارتباط ساختارى ميان سازههايى است كه

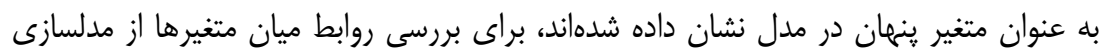

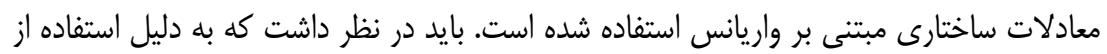

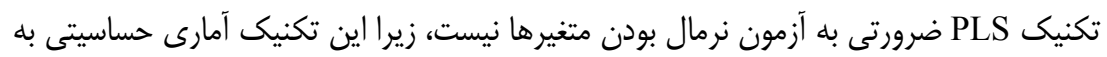

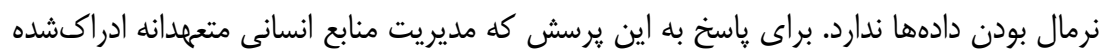

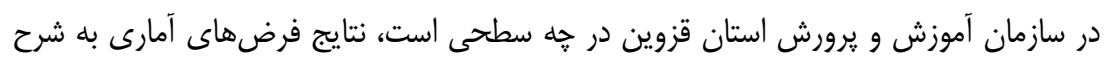

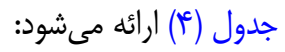

جدول †: آزمون مطلوبيت مديريت منابع انسانى با تعهد بالا

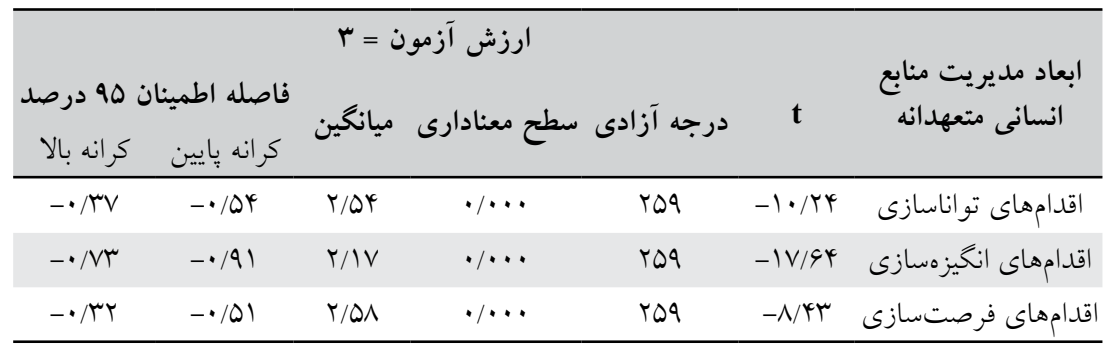

همانطور كه در جدول (أ) ديده مىشود، با توجه به منفى بودن مقادير T و و با محاسبه

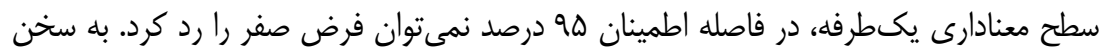

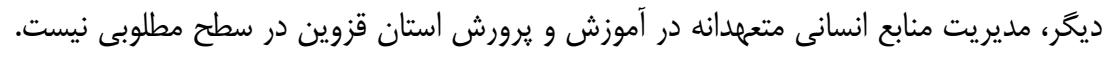

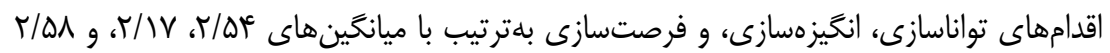

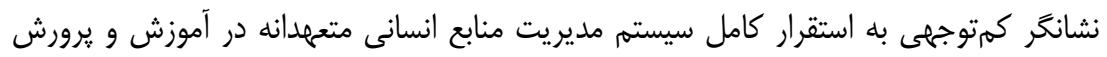




\section{مدل ساختارى}

براى ياسخ به اين يرسش كه خه روابط ساختارى ميان متغيرهاى يزوهش برقرار است، از

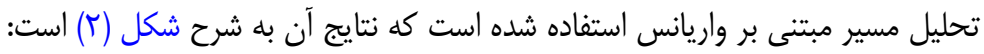

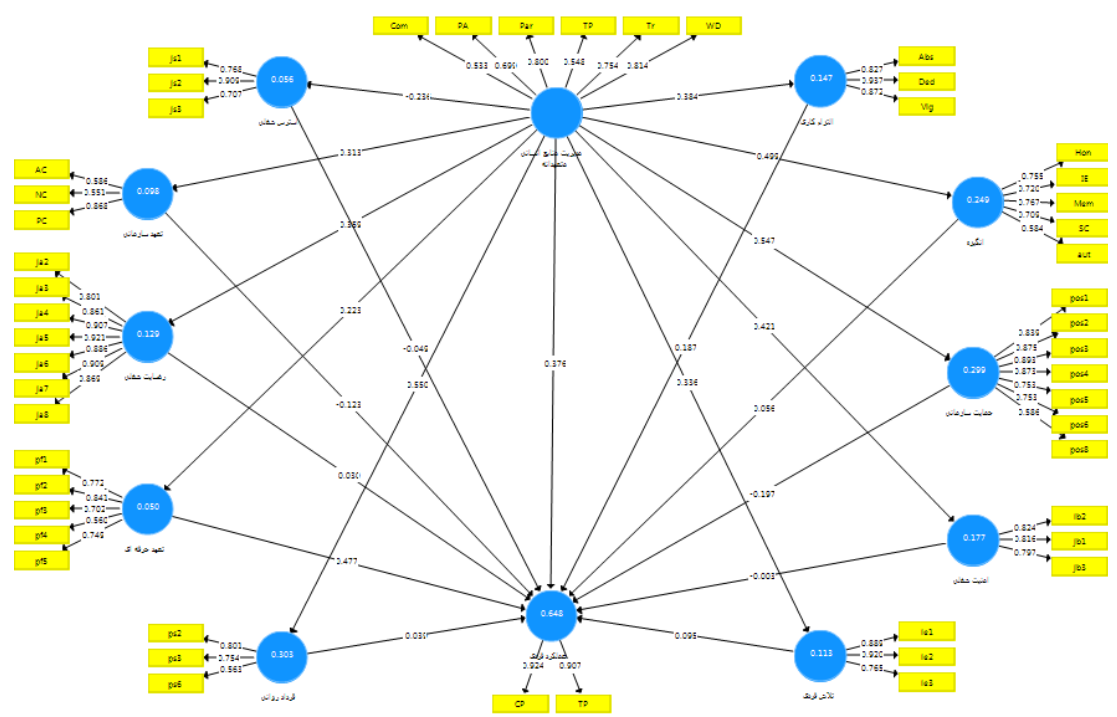

شكل r: مدل ساختارى در حالت ضرايب مسير استانداردشده

مقادير آلفاى كرونباخ، پايايى تركيبى، AVE، و ضريب تعيين مدل در جدول (ه) آمده است.

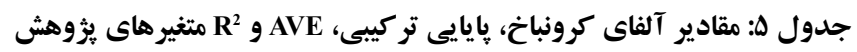

\begin{tabular}{|c|c|c|c|c|}
\hline سازهها & AVE & بِايايى تركيبى & ضريب تعيين (R) & آلفاى كرونباخ \\
\hline استرس شغلى & - NMG & $\cdot / \Lambda F$. & $\cdot 1 \cdot 09$ & $\cdot / N T^{4}$ \\
\hline التزام كارى & - /NOF &.$/ 911$ &.$/ N F$ & $\cdot / A \Delta Y$ \\
\hline امنيت شغلى & - MAY & - /NQY &.$/ \mathrm{VV}$ & - MYY \\
\hline انخيزه كارى & - /VDS & - /NHY & $. / T \times q$ & - /NQY \\
\hline تعهد حرفهاى & $\cdot / \mathrm{VW}$ & - /N $4 a$ & $\cdot / \cdot 0$ & $\cdot / \mathrm{NVV}$ \\
\hline تعهد سازمانى & $\cdot / 4 \wedge \Delta$ & $\cdot / 210$ & .1 .91 & $\cdot / 4 \wedge \Delta$ \\
\hline تلاش فردى & $\cdot / A Y Y$ & $\cdot / 190$ &.$/ 11 r$ & - /AYY \\
\hline
\end{tabular}


ادامه جدول ه: مقادير آلفاى كرونباخ، پايايى تركيبى، AVE و R متغيرهاى بروهش

\begin{tabular}{|c|c|c|c|c|}
\hline سازهها & AVE & بايايى تركيبى & ضريب تعيين (R) & آلفاى كرونباخ \\
\hline حمايت سازمانى & $\cdot / 9 \cdot 4$ &.$/ 949$ & $\cdot / 799$ & $\cdot / 9 \cdot x^{c}$ \\
\hline رضايت شغلى &.$/ 901$ &.$/ 99$. &.$/ 1 T q$ &.$/ 901$ \\
\hline عملكرد فردى & $\cdot / \Lambda \cdot V$ &.$/ 914$ &.$/ 94 \wedge$ & $\cdot / \Lambda \cdot V$ \\
\hline ق ق قرارداد روانى & $\cdot / 0 \cdot 1$ & - /VQY & $\cdot r \cdot r$ & $\cdot / 0 \cdot 1$ \\
\hline مديريت منابع انسانى متعهدانه & $\cdot / A \cdot r$ &.$/ 14 a$ & - & $\cdot / \Lambda \cdot Y$ \\
\hline
\end{tabular}

ميزان همبستخى يك سازه را با نشانكر هاى خود نشان مىدهد، و هرجه همبستخى

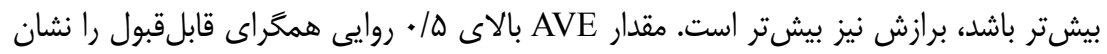

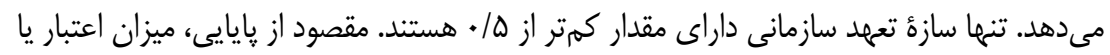

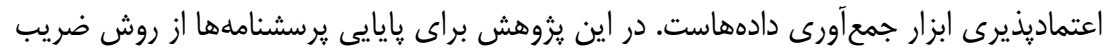

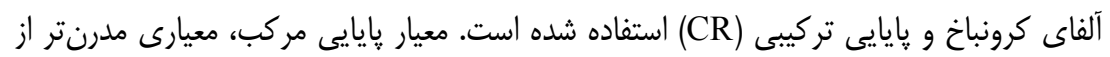

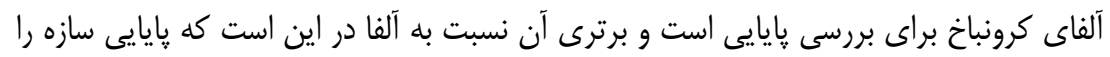

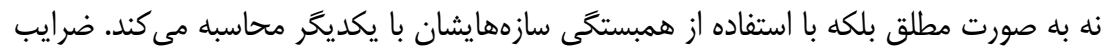

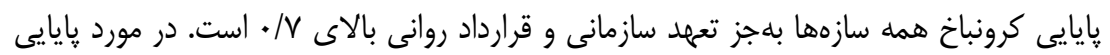

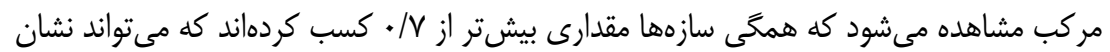
از تكراريذيرى و قابليت اعتماد برسشنامه باشده.

جدول \&: ماتريس فورنل ـ لار كر براى روايى واترا

\begin{tabular}{|c|c|c|c|c|c|c|c|c|c|c|c|c|}
\hline \multirow[t]{8}{*}{ مديريت } & قرارداد & فرملكرد & شغلى رضايت & سازمانى & $\begin{array}{l}\text { فردى } \\
\text { تلاش } \\
\text { (V) }\end{array}$ & سازمانى & حرفهاى & $\begin{array}{c}\text { كارىيزه } \\
\text { كارى }\end{array}$ & شغلى & $\begin{array}{c}\text { كارى } \\
\text { التزام } \\
\text { (Y) }\end{array}$ & شغتى استى & \\
\hline & & & & & & & & & & & $\cdot / V 99$ & (1) \\
\hline & & & & & & & & & & $\cdot / \Lambda \Lambda$. &.$- / T V A$ & (Y) \\
\hline & & & & & & & & & . & .494 & $-/ T \Delta \Delta$ & $(\Gamma)$ \\
\hline & & & & & & & & $\cdot / N 1$. & - /DFA & $.19 \mathrm{~V}$. & $-\cdot \pi \cdot \varphi$ & (Y) \\
\hline & & & & & & & $\cdot / N{ }^{\prime}$ &.$/ 419$ & $\cdot / \pi \mid 4$ & . $/ 0 Y G$ &.$- / .91$ & (Q) \\
\hline & & & & & & . /9Ar & $\cdot / \wedge \Delta \wedge$ & $\cdot / \Delta \Delta$. & $\cdot / \pi 91$ & . $/ \Delta \wedge r$ & $-\cdot / 1 \cdot r$ & (9) \\
\hline & & & & & $\cdot|\wedge 9|$ & $\cdot / 09 V$ & - /DKY & $\cdot N I Y$ & - /TNK &.$/ 94$. & $-\cdot / 1 \cdot r$ & (V) \\
\hline
\end{tabular}


ادامه جدول \&: ماتريس فورنل ـ لاركر براى روايى واترا

\begin{tabular}{|c|c|c|c|c|c|c|c|c|c|c|c|c|}
\hline مديريت & $\begin{array}{l}\text { قرارداد } \\
\text { روانى } \\
\text { (III) }\end{array}$ & 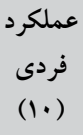 & رضلى رايت & سازمانى & $\begin{array}{l}\text { فردى } \\
\text { فلاش }\end{array}$ & $\begin{array}{c}\text { سازمانى } \\
\text { (8) }\end{array}$ & حرفهد & $\begin{array}{l}\text { كارى } \\
\text { انخيزه } \\
\text { (f) }\end{array}$ & 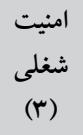 & $\begin{array}{c}\text { كارى } \\
\text { كام (Y) }\end{array}$ & شغتلى استر & \\
\hline & & & & $\cdot / \Lambda \cdot r$ & $\cdot / 1 Y q$ & $\cdot / 109$ & $-\cdot / \cdot Y T$ & - KOS & $\cdot r \cdot v$ &.$/ V K T$ & $-\cdot / / Q T$ & (^) \\
\hline & & & $\cdot / \Lambda \Lambda$. & $\cdot / 494$ & $\cdot / \kappa r$. & $\cdot / 4 N \mid$ & $\cdot M T Y$ & $.19 T V$ & . MAY & .1909 & $-\cdot / T+\wedge$ & (9) \\
\hline & &.$/ 910$ & $\cdot / 4 \mid r$ & $\cdot / \cdot M$ & $\cdot / 09 \Lambda$ & $\cdot / 099$ & $\cdot 1900$ & • & $\cdot / r q 4$ & .1911 &.$- / T H Y$ & (1.) \\
\hline & • VIT & $\cdot / \mu_{4}$ & $\cdot / \pi 9 \Lambda$ & $\cdot / \Delta \Delta \Delta$ & • $/ T V Y$ & $\cdot / r v r$ & $\cdot / T Y \Lambda$ & $\cdot / 0 \cdot x^{c}$ & - / FOr & $\cdot / r \Delta V$ & $-\cdot / r \cdot \wedge$ & (11) \\
\hline$\cdot N \cdot 1$ & $\cdot / 00$. & $\cdot / 01$. & $\cdot r \Delta q$ & $\cdot / Q F V$ & • & & שTKK & $\cdot / 499$ & $\cdot|K Y|$ & $\cdot / \Gamma \Lambda \psi$ & $-\cdot / T M G$ & $(I Y)$ \\
\hline
\end{tabular}

مجذور مقدار AVE در قطر اصلى قرار مى گيرد و جون اين مقدار از تمامى همبستخىهاى سطر و ستون مربوطه بيشتر است، روايى واگرا تاييد مىشود. ييش از بحث درباره ضرايب و بررسى فرضيهها، مقادير معنادارى ضرايب را كه با آماره T براى هر مسير ارائه مىشود. اگر مقدار ضريب مسيرى بيشتر از عه/ باشد، آنغاه آن ضريب در سطح خطاى ه درصد معنادار است

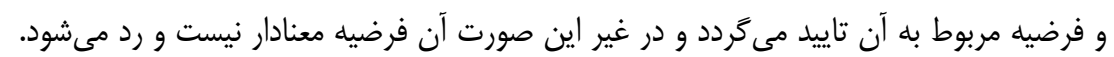

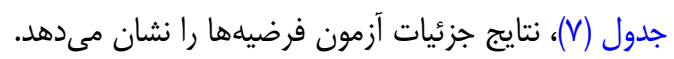

جدول \: ضرايب مسير و مقادير T

\begin{tabular}{|c|c|c|c|c|c|}
\hline $\mathbf{T}$ & انحتاندارد & 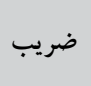 & 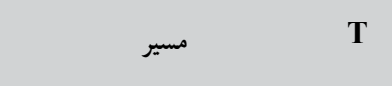 & ضريب استاندارد انحراف & 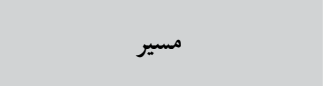 \\
\hline $1 \cdot 194$. & $\cdot / \cdot \Delta T$ & $\cdot / \Delta \& V$ & qMa/ • مديريت منابع به حمايت سازمانى & $\cdot / \cdot V 9$ & انخيزه كارى به عملكرد فردى \\
\hline$V / .91$ & $.1 \cdot 01$ & $\cdot /$ TQQ & 1094/ مديريت منابع به رضايت شغلى & .1 .90 & قرارداد روانى به عملكرد فردى \\
\hline$N / t^{\prime}$ & $\cdot / \cdot \Delta r$ & $\cdot /$ AYI & T/4 T مديريت منابع به امنيت شغلى & $\cdot 1 \cdot \mathrm{VA}^{4}$ & التزام كارى به عملكرد فردى \\
\hline$r / 9 M$ & $.1 \cdot 09$ & $-\cdot / r$ G & 1/Ora مديريت منابع به استرس شغلى & .1 .94 & تلاش فردى به عملكرد فردى \\
\hline $1 \cdot / 4 q$. & $\cdot / \cdot \Delta r$ & $\cdot / \Delta \Delta$ & P/N/R مديريت منابع به قرارداد روانى & $\cdot / \cdot 01-\cdot / 19 \mathrm{~V}$ & حمايت سازمانى به عملكرد فردى \\
\hline $0 / 099$ & $.1 \cdot 9$ & 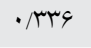 & F/TOQ مديريت منابع به تلاش فردى & $. / 11 \mathrm{r} \cdot / 4 \mathrm{EV}$ & تعهد حرفهاى به عملكرد فردى \\
\hline T/QTY & $\cdot / \cdot v 9$ & 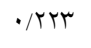 & 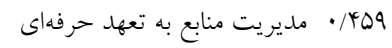 & $.1 .90 \quad \cdot / \cdot \mu$ & رضايت شغلى به عملكرد فردى \\
\hline$r / 9 \Delta r$ &.$/ \cdot 9 \mu$ & 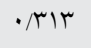 & 94×٪مديريت منابع به تعهد سازمانى & 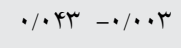 & امنيت شغلى به عملكرد فردى \\
\hline IT/KYA & $\cdot|\cdot|+1$ & $\cdot / 499$ & مديريت منابع به انخيزه كارى & $\cdot / 1 \cdot 1-\cdot / 1 \pi$ & تعهد سازمانى به عملكرد فردى \\
\hline \multirow[t]{2}{*}{$9 / \mathrm{V} 11$} & $\cdot / \cdot \Delta V$ & $\cdot / r \wedge r$ & مديريت منابع به التزام كارى & $1 / 11 \cdot-\cdot . / \cdot 49$ & استرس شغلى به عملكرد فردى \\
\hline & & & $9 / \mu \cdot 4$ & $\cdot /$ rVG & مديريت منابع انسانى به عملكردفردى \\
\hline
\end{tabular}


براى باسخ به اين برسش كه خه عواملى در رابطه بين مديريت منابع انسانى متعهدانه و

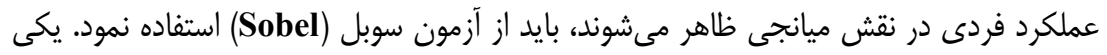

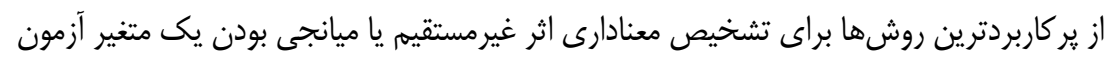
سوبل است. بلهور كلى، در آزمون سوبل مىتوان از تخمين نرمال براى بررسى معنادارى رابطه

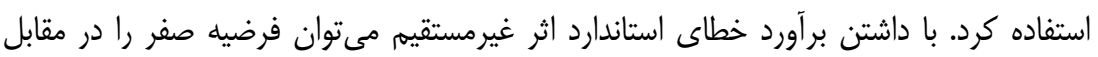

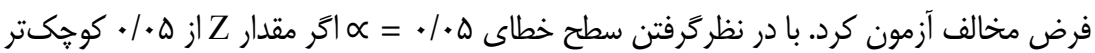

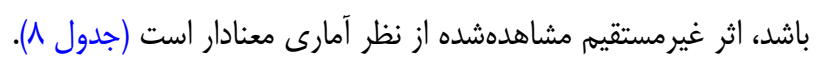




\section{جدول 1: آزمون ميانجى بودن متغيرها (آزمون سوبل)}

\begin{tabular}{|c|c|c|c|c|c|c|c|c|c|c|}
\hline مديريت منابع & مديريت منابع & حمايريت منابع به & مديريت منابع & منابع به تعهد مازيت & منابع به تعهد & مديريت منابع & مد امنيريت منابع & مدير التزام كارى منابع & مديريت منابع & مير مستقل به \\
\hline$\cdot / \Delta \Delta$. & $\cdot / T \Delta Q$ & $\cdot / D \& V$ & צחו & & • &.$/ 499$ & . $/ A Y I$ & $\cdot / r \wedge \psi$ & - - THG & ضريب مسير (a) \\
\hline$\cdot / \Delta r$ & .1 .01 &.$/ \Delta T$ & .1 .9$. & r. &.$/ \cdot V q$ & $.1 \cdot+4$ &.$/ \Delta T$ & $\cdot / \cdot \Delta V$ & .1 .09 & $\mathrm{Sa}$ \\
\hline قملرارداد روانى به & رضايت شغلى عملكرد & حمايت سازمانى مانه & تملاش فردى به & 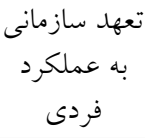 & تعهد حرفهاى فرملكرد & عملكيزه كارى فيه & غلم بـه| & . إ كا. & عملكرد فردى شغلى & مسير ميانجى ان \\
\hline $.1 \cdot r q$ & $\cdot / \cdot r$. &.$- / 19 \mathrm{~V}$ & .1 .90 & תו & $\cdot / 4 V V$ & $\cdot 1 \cdot \Delta 9$ & س & $\cdot / \Lambda \wedge \vee$ & $-\cdot 1 \cdot 4 q$ & ضريب مسير \\
\hline .1 .90 & .1 .90 & $\cdot / \cdot \Delta \wedge$ & .1 .94 & $\cdot / 1 \cdot 1$ &.$/ 11 Y$ & $\cdot / \cdot V G$ & . & $\cdot / \cdot V 9$ & $1 / 11$. & $\mathrm{Sb}$ \\
\hline$\cdot / 099$ & $\cdot / 401$ & $r / T 19$ & $1 / 4 \Delta G$ & $1 / \cdot 19$ & T/TVT & תMT/. & .1 .99 & 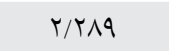 &.$/ \cdot k r$ & آماره سوبل \\
\hline بى معنا & بيىمعنا & معنادار & بي معنا & بى معنا & معنادار & بى معنا & بى بعنا & معنادار & بى معنا & نتيجه آزمون \\
\hline
\end{tabular}


با توجه به سطح معنادارى آزمون سوبل مىتوان متغيرهاى التزام كارى، تعهد حرفهاى، و

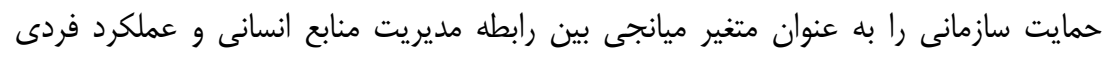
يذيرفت.

\section{برازش مدل}

در نرمافزار PLS معيار مناسب بودن مدل، ضريب تعيينى است كه براى مدل ارائه مىشود

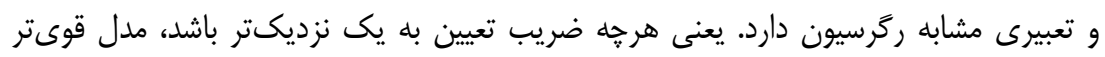

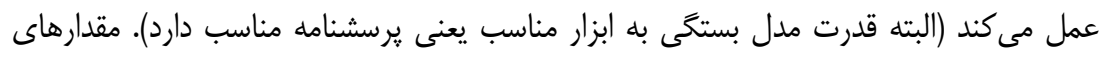

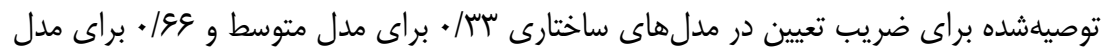

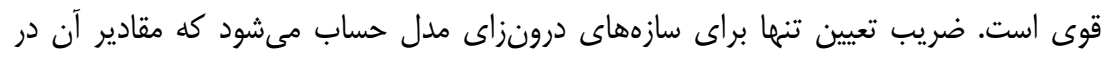

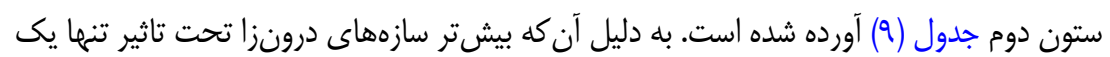
سازه برونزا هستند، براى اين يزوهش معيار اندازه اثر رابطه جندان مناسب و براى بيشتر سازهانها

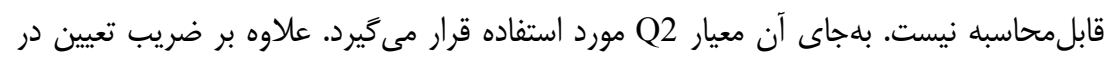

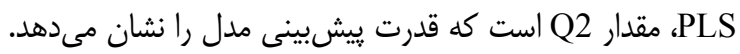

جدول q: شاخصهاى نيكويى برازش مدل

\begin{tabular}{|c|c|c|}
\hline سازهها & ضريب تعيين (R2) & Q2 معيار \\
\hline انخيزه كارى & $\cdot / r Q$ & $\cdot / \cdot V Q$ \\
\hline عملكرد فردى & .190 & . \\
\hline التزام كارى & .110 & $.1 \cdot 49$ \\
\hline حمايت سازمانى & $\cdot / \mu$ & $\cdot / 791$ \\
\hline رضايت شغلى & - ( & $\cdot / \cdot \wedge r$ \\
\hline امنيت شغلى & $\cdot / \Lambda$ & $\cdot / \cdot \wedge r$ \\
\hline استرس شغلى & .1 .4 & $-.1 \cdot 10$ \\
\hline قرارداد روانى & $\cdot / \mu$ & $\cdot / I V T$ \\
\hline تلاش فردى & .111 & $\cdot / \cdot 4$ \\
\hline تعهد حرفهاى & $\cdot 1 \cdot 0$ & $-\cdot / \cdot r$ \\
\hline تعهد سازمانى & $\cdot / 1$ &.$/ \cdot 14$ \\
\hline
\end{tabular}


با توجه به جدول (9)، ضريب تعيين عملكرد فردى (ه\&|•) در حد مناسب و قابلقبول است. به

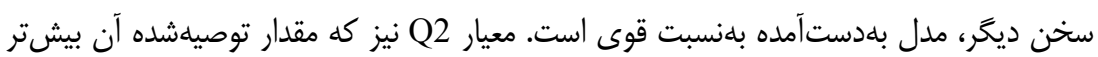

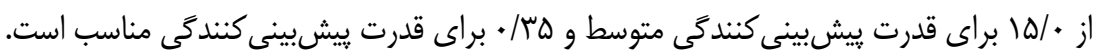

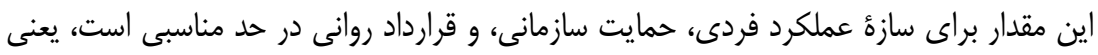

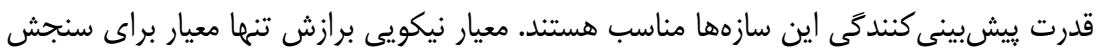

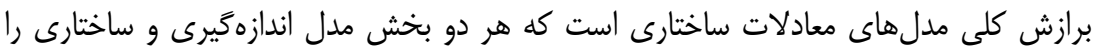

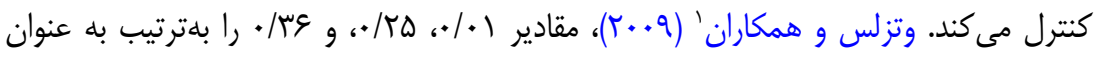
مقادير ضعيف، متوسط، و قوى براى نيكويى برازش كلى مدل تعيين مىنمايند. ميانكين مقادير

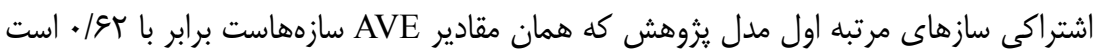

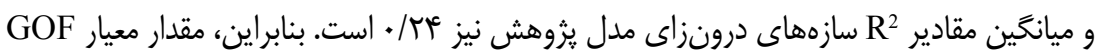

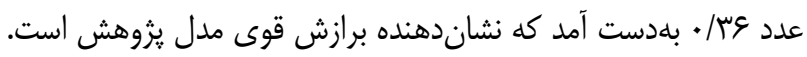

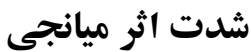

براى تعيين شدت اثر غيرمستقيم از طريق متغير ميانجى از آمارهاى به نام VAF استفاده

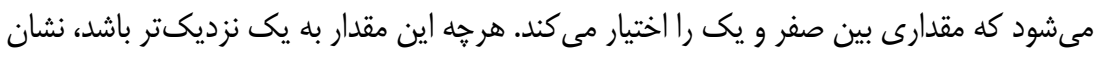

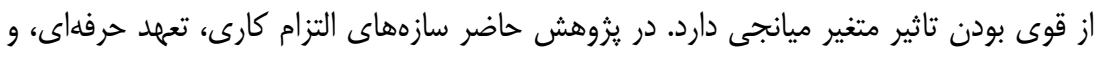

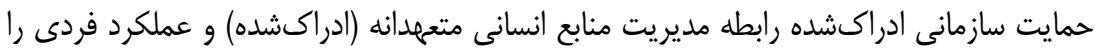

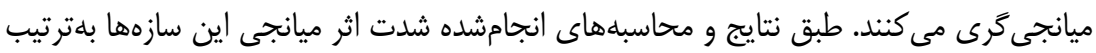
عا، الr، و •f درصد است (جدول +().).

جدول • ا: تعيين شدت اثر ميانجى

\begin{tabular}{|c|c|c|c|}
\hline مديريت منابع به حمايت & مديريت منابع به تعهد & مديريت منابع به التزام كارى & مسير مستقل به \\
\hline$\cdot / Q F V$ & • & $\cdot \pi \wedge F$ & ضريب مسير (a) \\
\hline عمايت سازمانى به & تعهل حرفهاى به عملكرد & التزام كارى به عملكرد فردى & مسير ميانجى به \\
\hline$-\cdot / 19 \mathrm{~V}$ & $\cdot / 4 V V$ & $\cdot / \backslash \wedge \mathrm{V}$ & ضريب مسير (b) \\
\hline
\end{tabular}

1. Wetzels et al. 
ادامه جدول • ا: تعيين شدت اثر ميانجى

\begin{tabular}{|c|c|c|c|}
\hline مديريت منابع به حمايت & مديريت منابع به تعهد & مديريت منابع به التزام كارى & مسير مستقل به \\
\hline & & مديريت منابع انسانى متعهدانه & مسير مستقل به \\
\hline & & • MVG & ضريب مسير (c) \\
\hline$-\cdot / 1 \cdot 1$ & $\cdot 11 \cdot 9$ & $\cdot / \cdot V T$ & $a \times b$ \\
\hline$\cdot$ TYA & $\cdot /$ FAr & $\cdot / 4 F A$ & $(a \times b)+c$ \\
\hline$-\cdot / 4$ & $\cdot / T 1$ & .119 & VAF \\
\hline
\end{tabular}

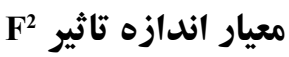

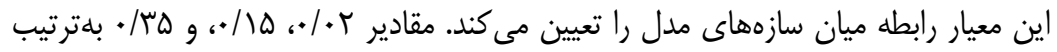

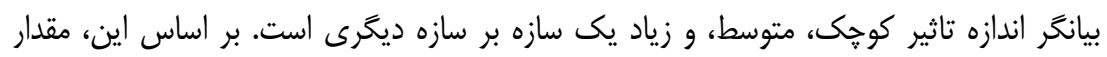

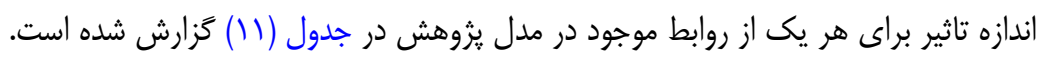

جدول 11: شاخص اندازه اثر رابطهها

\begin{tabular}{|c|c|c|c|}
\hline F2 اندازه اثر F2 & سازهها & اندازه اثر F2 & سازهها \\
\hline$\cdot / \cdots r$ & قرارداد روانى به عملكرد فردى & $\cdot / \cdot r$ & انخيزه كارى به عملكرد فردى \\
\hline$\cdot 1 \cdots 9$ & تلاش فردى به عملكرد فردى & $\cdot / T \backslash \wedge$ & مديريت منابع به عملكرد فردى \\
\hline$\cdot / 1 \mathrm{kr}$ & تعهل حرفهاى به عملكرد فردى & / & التزام كارى به عملكرد فردى \\
\hline$\cdot / \cdots \wedge$ & تعهد سازمانى به عملكرد فردى & $\cdot / \cdot \Delta r$ & حمايت سازمانى به عملكرد فردى \\
\hline \multirow[t]{2}{*}{$\cdot 1 \cdots 4$} & استرس شغلى به عملكرد فردى & $\cdot / \cdots 1$ & رضايت شغلى به عملكرد فردى \\
\hline & & $\cdot / \cdots$ & امنيت شغلى به عملكرد فردى \\
\hline
\end{tabular}

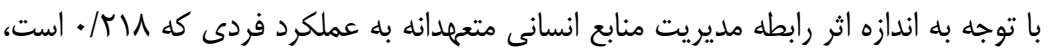

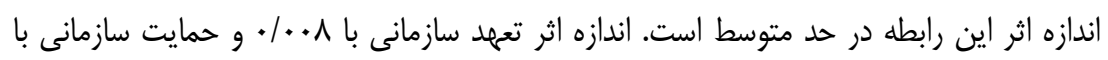

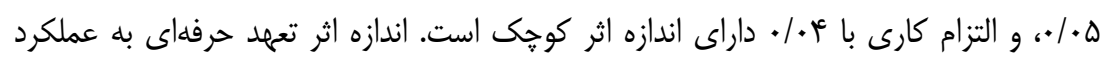

$$
\text { فردى نيز در حد متوسط است (س؟ / /•). }
$$




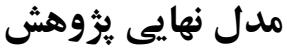

مدل نهايى مديريت منابع انسانى با تعهد بالا با توجه به ابعاد و مولفههاى ثزوهش و ارتباط

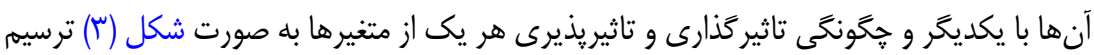
مى تردد.

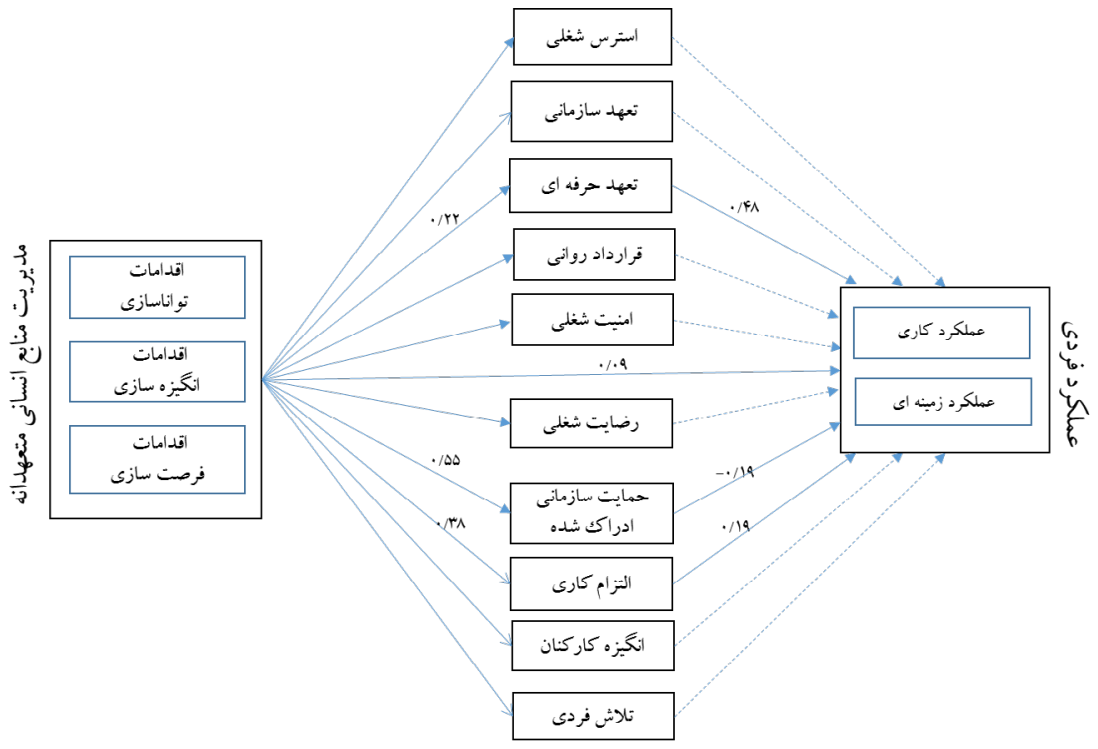

شكل "ז: مدل ساختارى آثار مديريت منابع انسانى متعهدانه

همانطور كه در شكل (با) ديده مىشود، مديريت منابع انسانى متعهدانه ضمن تاثير كذارى

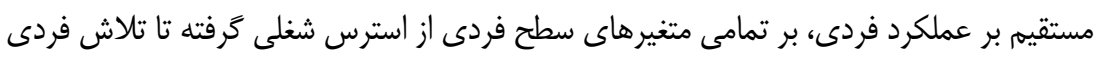

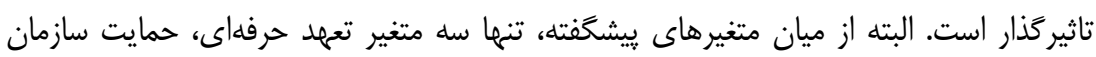
ادراكشده، و التزام كارى در رابطه بين مديريت منابع انسانى متعهدانه (ادراكشده) و عملكرد فردى در نقش ميانجى ظاهر مىشوند. 


\section{بحث و نتيجه كيرى}

يافتهاى ما ممكن است ييامدهاى مهمى براى شيوههاى مديريت منابع انسانى متعهدانه

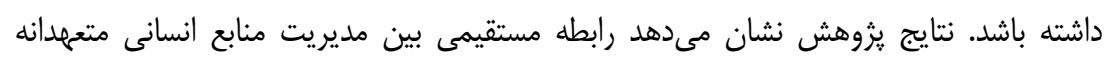

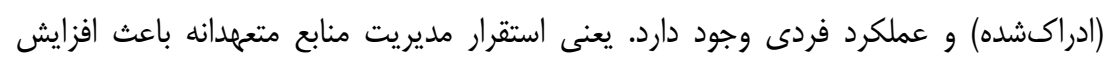

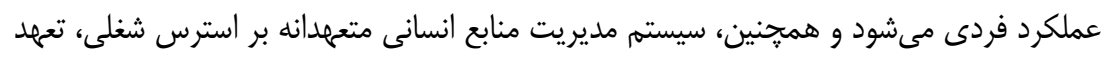

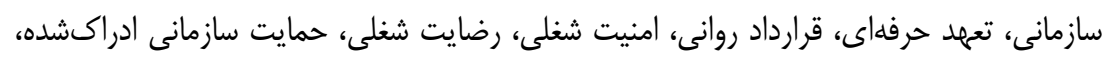

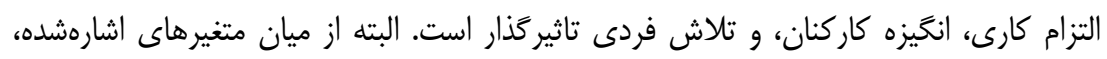

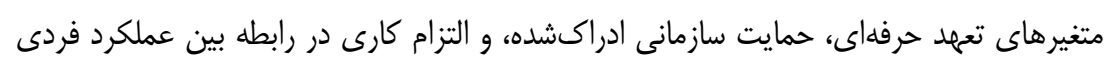

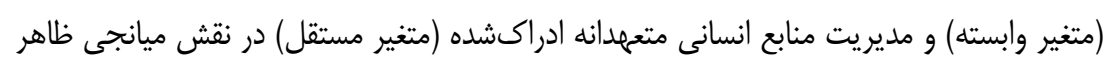

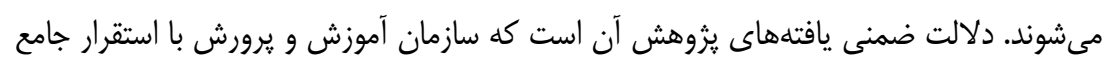

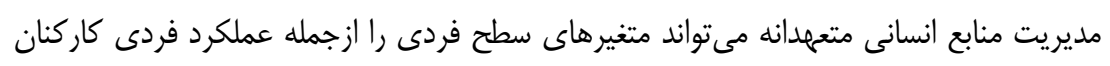

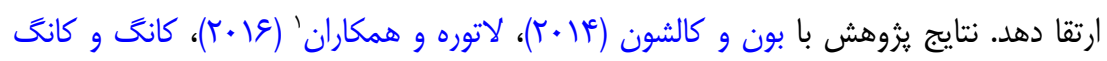

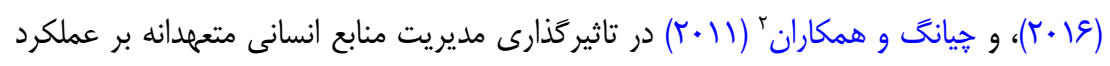
فردى هماهنگیى دارد.

يافتههاى اين يزوهش نشان مى دهد كه ابعاد سهكانه مديريت منابع انسانى متعهدانه در سازمان

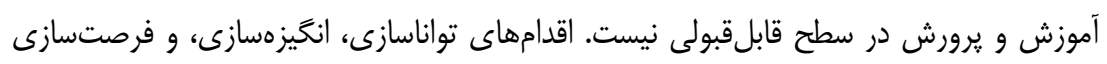

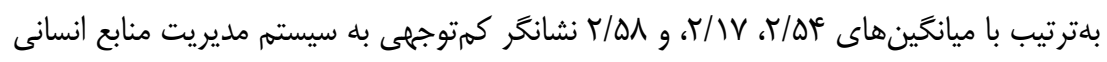

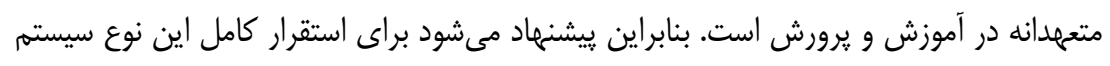

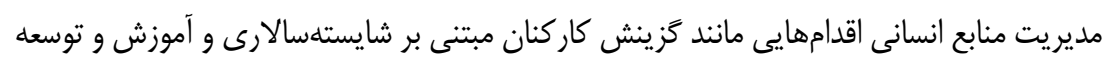

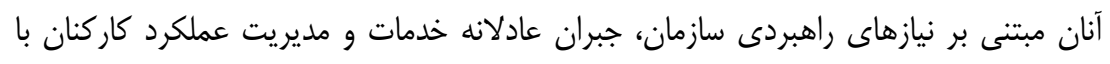

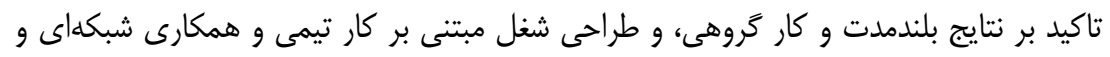

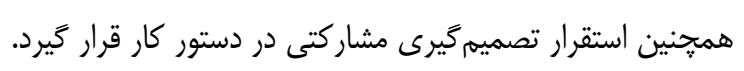

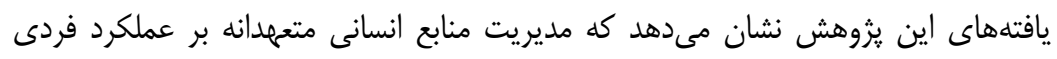

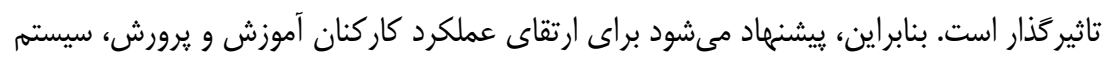

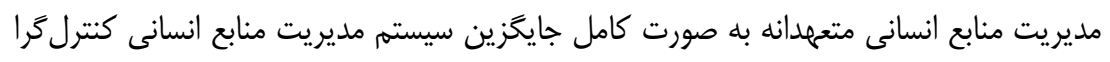

1. Latorre et al.

2. Chiang et al. 
يافتهاى اين يزوهش نشان مىدهد كه سيستم مديريت منابع انسانى متعهدانه هم بلهور

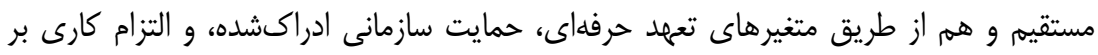

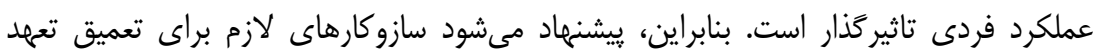

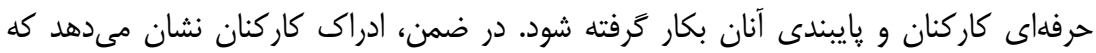

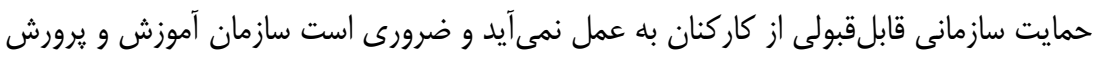

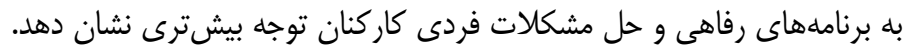

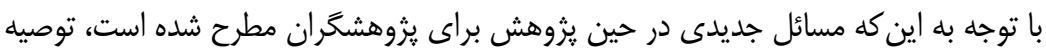

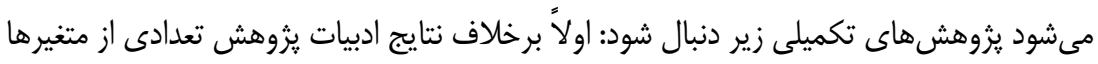
در نقش ميانجى ظاهر نشدند، كه اين موضوع مىتواند ناشى از عوامل تعديل كنندهاى باشد كه درد

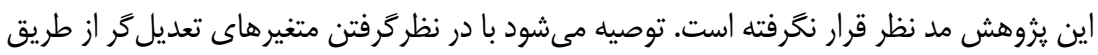

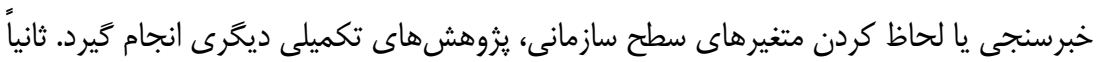

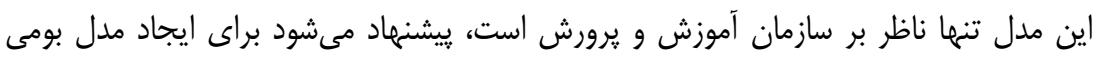

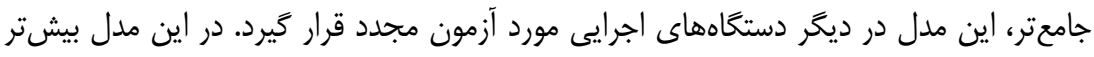

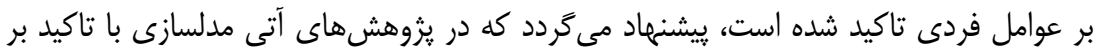
عوامل سطح گروهى و سازمانى دنبال شود.

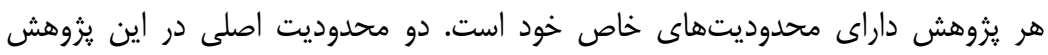

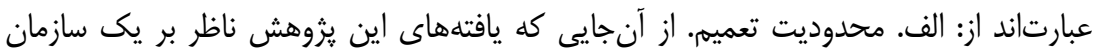

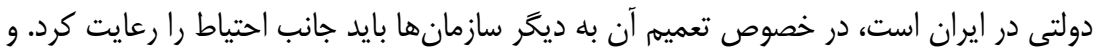

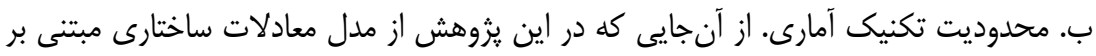

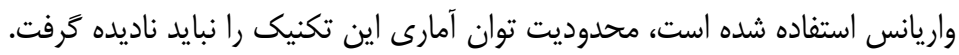

\section{منابع}

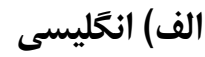

Arthur, J. B. (1994). Effects of Human Resource Systems on Manufacturing Performance and Turnover. Academy of Management Journal, 37(3), 670687. https://doi.org/10.5465/256705

Boon, C., \& Kalshoven, K. (2014). How High-Commitment HRM Relates to Engagement and Commitment: The Moderating Role of Task Proficiency. Human Resource Management, 53(3), 403-420. https://doi.org/10.1002/hrm.21569 
Boyne, G. A. (2002). Public and Private Management: What's the Difference? Journal of Management Studies, 39(1), 97-122. https://doi.org/10.1111/1467-6486.00284

Boyne, G., Poole, M., \& Jenkins, G. (1999). Human Resource Management in the Public and Private Sectors: An Empirical Comparison. Public Administration, 77(2), 407-420. https://doi.org/10.1111/1467-9299.00160

Brown, S. P., \& Leigh, T. W. (1996). A New Look at Psychological Climate and Its Relationship to Job Involvement, Effort, and Performance. Journal of Applied Psychology, 81(4), 358-368. https://doi.org/10.1037/0021-9010.81.4.358

Chiang, H. H., Han, T. S., \& Chuang, J. S. (2011). The Relationship between High-Commitment HRM and Knowledge-Sharing Behavior and Its Mediators. International Journal of Manpower, 32(5/6), 604-622. https://doi.org/10.1108/01437721111158224

Cruz, N. M., Pérez, V. M., \& Cantero, C. T. (2009). The Influence of Employee Motivation on Knowledge Transfer. Journal of Knowledge Management, 13(6), 478-490. https://doi.org/10.1108/13673270910997132

Dalal, R. S. (2005). A Meta-Analysis of the Relationship between Organizational Citizenship Behavior and Counterproductive Work Behavior. Journal of Applied Psychology, 90(6), 1241-1255. https://doi.org/10.1037/0021-9010.90.6.1241

Datta, D. K., Guthrie, J. P., \& Wright, P. M. (2005). Human Resource Management and Labor Productivity: Does Industry Matter? Academy of Management Journal, 48(1), 135-145. https://doi.org/10.5465/amj.2005.15993158

Eisenberger, R., Huntington, R., Hutchison, S., \& Sowa, D. (1986). Perceived Organizational Support. Journal of Applied Psychology, 71(3), 500-507. https://doi.org/10.1037/0021-9010.71.3.500

Farnham, D., \& Giles, L. (1996). People Management and Employment Relations. In Managing the New Public Services (pp. 112-136): Springer. https://doi.org/10.1007/978-1-349-24723-3_6

Gould-Williams, J. (2004). The Effects of 'High Commitment'HRM Practices on Employee Attitude: The Views of Public Sector Workers. Public Administration, 82(1), 63-81. https://doi.org/10.1111/j.0033-3298.2004.00383.x

Guest, D. E. (1997). Human Resource Management and Performance: A Review and Research Agenda. International Journal of Human Resource Management, 8(3), 263-276. https://doi.org/10.1080/095851997341630

Hays, S. W., \& Kearney, R. C. (2001). Anticipated Changes in Human Resource Management: Views from the Field. Public Administration Review, 61(5), 585-597. https://doi.org/10.1111/0033-3352.00129

Hitt, M. A., Miller, C. C., \& Colella, A. (2006). Organizational Behaviour: A Strategic Approach: John Wiley \& Sons.

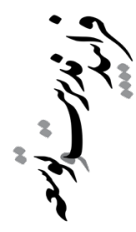


Jauch, L. R., Glueck, W. F., \& Osborn, R. N. (1978). Organizational Loyalty, Professional Commitment, and Academic Research Productivity. Academy of Management Journal, 21(1), 84-92. https://doi.org/10.5465/255664

Jiang, K., Lepak, D. P., Hu, J., \& Baer, J. C. (2012). How Does Human Resource Management Influence Organizational Outcomes? A MetaAnalytic Investigation of Mediating Mechanisms. Academy of Management Journal, 55(6), 1264-1294. https://doi.org/10.5465/amj.2011.0088

Kang, S.-W., \& Kang, S.-D. (2016). High-Commitment Human Resource Management and Job Stress: Supervisor Support as a Moderator. Social Behavior and Personality: An International Journal, 44(10), 1719-1731. https://doi.org/10.2224/sbp.2016.44.10.1719

Keller, R. T. (1984). The Role of Performance and Absenteeism in the Prediction of Turnover. Academy of Management Journal, 27(1), 176-183. https://doi.org/10.5465/255965

Koopmans, L., Bernaards, C. M., Hildebrandt, V. H., de Vet, H. C., \& van der Beek, A. J. (2014). Measuring Individual Work Performance: Identifying and Selecting Indicators. Work, 48(2), 229-238.

Kwon, K., Bae, J., \& Lawler, J. J. (2010). High Commitment HR Practices and Top Performers. Management International Review, 50(1), 57-80. https://doi.org/10.1007/s11575-009-0023-6

Latorre, F., Guest, D., Ramos, J., \& Gracia, F. J. (2016). High Commitment HR Practices, the Employment Relationship and Job Performance: A Test of a Mediation Model. European Management Journal, 34(4), 328-337. https://doi.org/10.1016/j.emj.2016.05.005

Meyer, J. P., \& Allen, N. J. (1997). Commitment in the Workplace: Theory, Research, and Application: Sage Publications.

Osborne, D., \& Plastrik, P. (1997). Banishing Bureaucracy: The Five Strategies for Reinventing Government: ERIC.

Pfeffer, J., \& Jeffrey, P. (1998). The Human Equation: Building Profits by Putting People First: Harvard Business Press.

Price, J. L. (1997). Handbook of Organizational Measurement. International Journal of Manpower, 18(4/5/6), 305-558. https://doi.org/10.1108/01437729710182260

Prieto, I. M., \& Pilar Pérez Santana, M. (2012). Building Ambidexterity: The Role of Human Resource Practices in the Performance of Firms from Spain. Human Resource Management, 51(2), 189-211. https://doi.org/10.1002/hrm.21463

Renz, D. O. (2016). The Jossey-Bass Handbook of Nonprofit Leadership and Management: John Wiley \& Sons.

Rotundo, M., \& Sackett, P. R. (2002). The Relative Importance of Task, 
Citizenship, and Counterproductive Performance to Global Ratings of Job Performance: A Policy-Capturing Approach. Journal of Applied Psychology, 87(1), 66-80. https://doi.org/10.1037/0021-9010.87.1.66

Rousseau, D. (2000). Psychological Contract Inventory Technical Report. Heinz School of Public Policy and Management: Carnegie Mellon University.

Rousseau, D., Schalk, R. (2000). Psychological Contracts in Employment: Cross-National Perspectives: Sage Publications.

Schaufeli, W., Taris, T., Le Blanc, P., Peeters, M., Bakker, A., \& De Jonge, J. (2001). Maakt arbeid gezond. Op zoek naar de bevlogen werknemer. De Psycholoog, 422-428.

Sun, L.-Y., Aryee, S., \& Law, K. S. (2007). High-Performance Human Resource Practices, Citizenship Behavior, and Organizational Performance: A Relational Perspective. Academy of Management Journal, 50(3), 558-577. https://doi.org/10.5465/amj.2007.25525821

Wetzels, M., Odekerken-Schröder, G., \& Van Oppen, C. (2009). Using PLS Path Modeling for Assessing Hierarchical Construct Models: Guidelines and Empirical Illustration. MIS Quarterly, 33(1), 177-195.

Whitener, E. M. (2001). Do "High Commitment" Human Resource Practices Affect Employee Commitment? A Cross-Level Analysis Using Hierarchical Linear Modeling. Journal of Management, 27(5), 515-535. https://doi.org/10.1177/014920630102700502

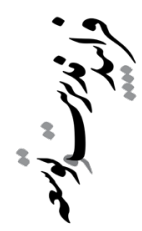

